\title{
La inconstitucionalidad por omisión. Necesidad de reconocimiento de la figura en Colombia como factor garantista de los Derechos Humanos
}

\section{Unconstitunational by Omission the Need for the Acknoledgment of this Legal. Figure in Colombia as a Factor which guarantees Human Rights}

Luis Bernardo Díaz Gamboa *

Fecha de recepción: 26 de marzo de 2008 Fecha de aprobación: 16 de abril de 2006

A todo principio de Derecho acompaña la seguridad de que el Estado se obliga a sí mismo a cumplirlo, lo cual es una garantía para los sometidos al Derecho.

Jellinek

\section{Resumen}

La Asamblea Nacional Constituyente colombiana no aprobó la figura de la inconstitucionalidad por omisión. Esta figura aplicada en otros ordenamientos jurídicos es fundamental para la defensa de los principios que dieron origen de la Constitución Política. La figura de la inconstitucionalidad por omisión busca garantizar que la voluntad del constituyente tenga plena realización y no que se desnaturalice. La materialización constitucional tiene su negación en la desvalorización inercial de la Carta; puede existir una violación por omisión en el desarrollo de los tratados internacionales de Derechos Humanos, debidamente suscritos y ratificados por un Estado, pudiendo comprometer el bloque de constitucionalidad.

\section{Palabras clave}

inconstitucionalidad por omisión, Derecho constitucional, defensa de la constitución. 


\begin{abstract}
Colombia's National Constitutional Assembly did not approve the legal figure of unconstitutionality by omission. This figure, which is fundamental for the defence of the principles on which the political constitution is based, seeks to guarantee that the will of the Constitutional Assembly is carried out in full and that erosion does not occur. The materialisation of the Constitution has its negation in the inertial devaluation of the Magna Carta. What may occur is a violation of the constitutional principles by omission in the development of the international human rights treaties, which, although properly signed and ratified by a State, could compromise the constitutional block as a whole.
\end{abstract}

\title{
Key words
}

Unconstitutionality by omission, constitutional law, defence of the constitution

\section{INTRODUCCIÓN}

La Asamblea Nacional Constituyente colombiana no aprobó la figura de la inconstitucionalidad por omisión, aunque sí dio vía libre a otras acciones de gran importancia, como la tutela, la acción de cumplimiento, las acciones populares y de grupo, entre otras, que buscan garantizar la Carta de Derechos inserta en la Constitución Política. La norma constitucional supone el nacimiento de una obligación de desarrollo ulterior.

Catorce años después de expedida la Carta Política se produjo una inacción lesiva del espíritu y la letra de ésta por parte del poder Legislativo, dado que en aquella fecha no se habían reglamentado varios de los artículos constitucionales, como la Ley de Ordenamiento Territorial, el Estatuto del Trabajo, el derecho de huelga, entre otros, con el grave deterioro de la credibilidad institucional que ello conllevaba. La democracia es un proceso que precisa su permanente y sostenido perfeccionamiento. No basta la expedición de una Carta Política, si ésta no se desarrolla ni se enriquece.

La efectividad, el funcionamiento, la aplicabilidad y la vigencia sociológica son factores fundamentales para la eficacia, la validez o la vinculatoriedad de la Constitución. Hoy en día las constituciones intentan cumplir funciones de promoción y redis- tribución de bienestar social y económico. Con ello se pretende constituir en un motor transformador de la sociedad. Cualquier inacción, inercia o quiescencia perturba esta función vital, que alimenta la propia democracia. Por lo anterior se habla del "fraude" del Legislativo cuando dilata sine die la reglamentación de un artículo de la Ley de Leyes. Se requiere, entonces, una respuesta de índole constitucional efectiva, que supere la crisis del poder Legislativo en la materia, que lo disponga a actuar de forma ágil en su propia función.

Se debe buscar que la voluntad del constituyente tenga plena realización y no que se desnaturalice. La materialización constitucional tiene su negación en la desvalorización inercial de la Carta; puede existir una violación por omisión en el desarrollo de los tratados internacionales de Derechos Humanos, debidamente suscritos y ratificados por un Estado, pudiendo comprometer el bloque de constitucionalidad. Como dijo Jellineck: "el Derecho se caracteriza por su eficacia". La actitud de "rémoras parlamentarias" no favorece este apotegma. Como dice Ihering: "Sólo merece la libertad y la vida el que cada día sabe conquistarlas" (1985, p. 136).

La figura de la inconstitucionalidad por omisión puede ser la espada que, empuñada por la Corte Constitucional, o por la opinión pública, obligue el desarrollo de aquello que resta por hacer. De esta 
manera, tal vez se logren consecuencias positivas, sin duda un tanto imprevisibles, las cuales irán desde la realización del proyecto constitucional hasta la participación en la búsqueda de soluciones a la crisis del Estado Social, crisis que también fomenta la del Estado democrático y la del Estado de Derecho. Ante tal planteamiento es posible esgrimir importantes argumentos en su contra, como lo se verá posteriormente.

Entre estos argumentos brilla con luz propia la libertad de configuración del Legislador. También juega papel importante la posible atribución al Alto Tribunal de una faceta o función más, que frisa con la de "legislador positivo", aunque sin entrar en ella, la cual se añadiría a las que ya posee, entre las que destaca la de "legislador negativo" o monopolizador de la declaración de inconstitucionalidad de las leyes, exponente máximo de la función de control que realiza.

Loewenstein se expresa así al referirse a la inaplicación de la Constitución:

\begin{abstract}
Una disposición constitucional se puede presentar desde el primer momento como irrealizable. Sin embargo, en la mayor parte de los casos, las razones de esta inobservancia son de tipo puramente político: el convencimiento del gobierno, actualmente dominador del poder, de que la aplicación de dicha disposición iría contra sus interés específicos; la aversión de la constelación de partidos que controlan la asamblea legislativa contra la disposición en cuestión; la presión social y económica de determinados grupos de interés contra su realización; factores de política exterior (Loewenstein, 1986, pp. 223-224).
\end{abstract}

La Constitución, entonces, no se puede concebir como un mero conjunto de principios políticos. La idea de inconstitucionalidad por omisión en el contexto de un concepto normativo de Constitución ya no se traduce en un mecanismo, que trata de asegurar el carácter vinculante a los preceptos del Texto Fundamental ni en un instrumento, que busca sujetar a ulteriores mayorías políticas, sino que camina en torno a la consecución de una efectividad total de los preceptos constitucionales, que ya son de por sí vinculantes. Este aspecto se liga instintivamente a la garantía de la supremacía de la Constitución, la defensa de los derechos y libertades fundamentales, la idea de control y equilibrio de los poderes y la integración con base en valores son razones que hablan por sí mismas para defender la legitimidad de un órgano de justicia constitucional.

\section{Para Bidart Campos:}

[...] nos empeñamos en sugerir que los valores y los principios constitucionales no solamente deben operar cuando una norma o un acto infraconstitucionales los lesionan, sino también -en sentido positivo- cuando no les dan desenvolvimiento, aspecto éste que se equipara a la omisión constitucional. La Constitución se vulnera no solamente cuando se hace lo que ella prohíbe hacer, sino también cuando se deja de hacer lo que ella manda que se haga. No hay zona alguna de reserva que el ejecutivo, el Congreso o la administración puedan invocar para eximirse de hacer lo que la Constitución manda que hagan (Bidart Campos, 1997, pp. 2-3).

La ineficacia constitucional se erige como disvalor. Una situación de ineficacia predicada de un precepto constitucional es algo censurable desde los más variados ángulos de análisis. Desde la técnica del Derecho Constitucional la ineficacia supone un quebrantamiento, en última instancia, de la cualidad de norma jurídica de los preceptos constitucionales de que se trate, dado el sinsentido en el que recae, con el paso del tiempo, un precepto válidamente establecido pero alejado, a causa del rasgo de ineficacia que presenta, de la regulación de la realidad para la que fue creado. Al mismo tiempo, el "fraude" al proyecto constitucional y a la vinculatoriedad de la obra del poder constituyente también se hace patente. 
Una sencilla definición de la inconstitucionalidad por omisión es la falta de desarrollo por parte del Poder Legislativo, durante un tiempo excesivamente largo, de aquellas normas constitucionales de obligatorio y concreto desarrollo, de forma tal que se impide su eficaz aplicación. Omisión significa no hacer aquello a lo que se estaba constitucionalmente obligado. No basta en sí el deber general de legislar para tipificar la omisión inconstitucional, sino que debe estar vinculado con una exigencia constitucional de acción.

\section{CONSTITUCIÓN COMO NORMA}

Con la figura de la inconstitucionalidad por omisión se trata de hacerle frente a las Ilamadas rémoras parlamentarias, por cuanto existe un derecho ciudadano a la legislación pronta, oportuna y conveniente. Es exigible, pues, la necesidad de actuación de los poderes constituidos.

Loewenstein afirmo, al referirse a la inaplicación de la Constitución:

\begin{abstract}
Una disposición constitucional se puede presentar desde el primer momento como irrealizable. Sin embargo, en la mayor parte de los casos, las razones de esta inobservancia son de tipo puramente político: el convencimiento del gobierno, actualmente dominador del poder, de que la aplicación de dicha disposición iría contra sus intereses específicos; la aversión de la constelación de partidos que controlan la asamblea legislativa contra la disposición en cuestión; la presión social y económica de determinados grupos de interés contra su realización; factores de política exterior (Lowenstein, 1986, pp. 223-224).
\end{abstract}

Es por esto que surge la necesidad de crear un instrumento procesal de salvaguardia del derecho a la legislación oportuna. La Constitución no es un simple conjunto de principios políticos. La idea de inconstitucionalidad por omisión surge dentro del concepto de un contexto normativo de
Constitución -como brillantemente lo presenta García de Enterría (1991) -, el cual gira en torno a la consecución de una efectividad total de los preceptos constitucionales, que ya son per se vinculantes; no podría entonces estar sujeto a las variaciones y veleidades de las mayorías políticas coyunturales, salvo en el caso de una reforma constitucional que altere el sistema de fuentes y la parte dogmática y orgánica.

Son diferentes los preceptos constitucionales afectados con la omisión constitucional y asimismo, serán los grados de interés. Se puede hacer una distinción, a manera de ejemplo, entre la afectación al omitir el desarrollo de un relevante derecho fundamental, cuando tal desarrollo es necesario para su efectividad, es decir, cuando requiere interpositio legislatoris, puede tener una importancia que supere con creces, por ejemplo, el no desenvolvimiento de un órgano previsto en la Norma Normarum, pero de efectividad escasa e interés relativo.

En la Carta colombiana de 1991 veintitrés artículos son de aplicación inmediata -como lo refiere el art. 85-, ello aunado a las interpretaciones de la Corte Constitucional, que amparan los derechos fundamentales, ha permitido un grado de desarrollo importante, que pretendió ser desconocido por el proyecto de reforma a la justicia presentado por el anterior Ministro del Interior y de Justicia y que restringía la acción de tutela de forma lesiva contra Ios Derechos Económicos Sociales y Culturales y las propias sentencias, en un Estado que ni siquiera puede pagar cumplidamente las prestaciones de los defensores públicos, como quiera que hace un tiempo tuvo el Defensor del Pueblo ir a mendigar a Palacio para que le apropiaran las partidas necesarias para poder cumplir las obligaciones legales a favor de la asistencia jurídica en más de 70.000 expedientes como garantes de la defensa técnica. La legitimidad de la Corte Constitucional parte de reconocer la garantía de la supremacía de la Constitución, la defensa de los derechos y 
libertades fundamentales, la idea de control y de equilibrio de los poderes y la integración con base en las razones axiológicas imperativas.

La Constitución, como norma, se traduce en la pretensión de validez de las normas materiales de la Constitución, que a todos los poderes vinculan y a cuyo logro último se debe orientar la actuación de todos los poderes públicos. Ya no se puede hablar del viejo dogma de la soberanía absoluta del Parlamento, sino de la soberanía popular basada en la soberanía constitucional. La Carta Magna es una verdadera norma jurídica y no una promulgación de principios románticos, por lo cual tiene fuerza vinculante bilateral, obliga a los poderes públicos tanto como a los ciudadanos.

\section{CONSTITUCIÓN DIRIGENTE}

En términos de Gomes Canotilho (1993), la constitución es vinculante o constitución dirigente. Con esto se alude a un programa de actuación futura, que tiene que ser llevada a cabo por los poderes constituidos y así llegar a una sociedad más avanzada bajo la inspiración del principio de igualdad material. El Derecho Constitucional es un derecho no dispositivo, no es discrecional, sino que impulsa sus actuaciones por sendas prefijadas. El constituyente ha diseñado una estructura que se debe respetar. La inconstitucionalidad por omisión aparece en ese esquema como un poderoso instrumento, al menos en el campo político, para el desarrollo de los planes preconcebidos y con objetivos establecidos.

Los preceptos de la Carta Magna no son meros enunciados programáticos que "invitan" a los poderes públicos a una actuación determinada sin imponérsela. Por el contrario, los preceptos del Texto Fundamental son verdaderas normas jurídicas, aunque no todas de igual significación y trascendencia, que imponen comportamientos y modos de actuar de forma imperativa y no sujetos al arbitrio de la voluntad de los poderes constituidos, salvo que expresamente así lo prevea la misma disposición constitucional. Esto es especialmente palpable en aquellas normas que se traducen en obligaciones que sujetan a esos órganos de poder. No en vano, "todas las normas ya sea inmediata o mediatamente son la expresión de un mandato imperativo" (Segura Ortega, s.f., p. 88). Los valores constitucionales se erigen como guía para la interpretación judicial y para el Legislador.

Un problema atinente a los tratados y relativo a los derechos fundamentales es el no cumplimiento de las obligaciones de desarrollo que impone la normativa internacional de los derechos humanos y que en Colombia involucra el denominado bloque de constitucionalidad de claro arraigo francés. Es el caso de las exigencias procesales que recoge el Pacto Internacional de Derechos Económicos y Sociales (PIDESC).

El art. 3.2 de la Constitución Italiana establece que:

[...] es misión de la República remover los obstáculos de orden económico y social que limitando de hecho la libertad y la igualdad de los ciudadanos, impiden el pleno desenvolvimiento de la personalidad humana y la efectiva participación de todos los trabajadores en la organización política y social del país.

El art. 9.2 de la Carta Española sigue tal enunciado y en el 13 de la colombiana se expresa que “El Estado promoverá las condiciones para que la igualdad sea real y efectiva y adoptará medidas a favor de grupos discriminados o marginados". Como se puede observar, la Constitución cumple una función transformadora de la sociedad, que debe ser respondida con altura por los poderes públicos. La Constitución tiene función transformadora e integradora. La existencia del Estado Social de Derecho se traduce en una necesidad de actuación activa, incorporando una potente carga de progreso y de desarrollo en libertad. 


\section{INTERROGANTES DERECHO COMPARADO}

Desde luego, en Colombia, ahora que se entreabre el telón -nuevamente- de la reforma política, cabe formular los siguientes interrogantes: icuál es el tiempo razonable para la reglamentación de una norma?; ¿cuándo debe ser desarrollada la Constitución?; iqué pasa cuando se hunde la iniciativa legislativa?; ¿ 0 cuando la iniciativa es del Ejecutivo y no la presenta? Necesariamente se tiene que aportar en ese análisis algunas visiones, que distancian la figura de la acción de tutela, las populares y la de cumplimiento, mecanismos todos ellos de otra naturaleza indubitablemente, aunque si bien no se pretende agotar el tema en esta ocasión.

La doctrina clasifica la inactividad del Estado en dos tipos:

- La inacción, en general, de los poderes públicos, que corresponde con la no emisión de actos administrativos y públicas decisiones judiciales.

- La inacción el Legislativo, o inercia del Congreso.

Evidentemente, existe una violación constitucional, que es provocada por la inactividad del legislativo, la cual incide determinantemente en la pérdida de eficacia de la propia Lex Legum. La interpositio legislatoris permite concretar el sentido general de la Carta, que es norma de normas y garantizar su eficacia.

La figura de la inconstitucionalidad por omisión existió ya en la Constitución de Portugal de 1976 y en la Carta Brasileña de 1988; en nuestro hermano país brasileño hay una figura muy importante, el mandado de injuncao que se parece a nuestra acción de cumplimiento, pero que se diferencia de la inconstitucionalidad por omisión, cuya declaratoria debe estar en cabeza del máximo guardián de la Carta.
Como ha dicho la doctrina lusitana, es el debate entre la "Constitución-contrato" y la "Constituciónpromesa", que contiene hermosos elementos de lirismo programático poco exigibles del Estado, situación que debilita la credibilidad institucional. La Constitución abierta exige la compatibilidad entre contenido y realidad social.

Por su parte, el Tribunal Constitucional español, en sentencia de 18 de noviembre de 1983, estableció que quienes ejercen los poderes públicos tienen -además del deber general negativo de abstenerse de cualquier actuación que viole la Constitución-, un deber general positivo de cumplir sus funciones de acuerdo con ella, y que la Constitución obliga a todos, es decir, ciudadanos y poderes públicos. El propio artículo 9.1 de la Carta Española dice: "Los ciudadanos y los poderes públicos están sujetos a la Constitución y al resto del ordenamiento jurídico". También el art. 3 de la Constitución italiana es clara al afirmar que:

[...] incumbe a la República, remover los obstáculos de orden económico y social que, limitando de hecho la libertad y la igualdad de los ciudadanos, impidan el pleno desarrollo de la persona humana y la efectiva participación de todos los trabajadores en la organización política, económica y social del país.

En la Península Ibérica el Tribunal Constitucional ha recurrido a una serie de técnicas con las que ha enfrentado el problema de las omisiones legislativas: recomendaciones al legislador, sentencias aditivas, declaración de la inconstitucionalidad parcial de una norma por vulneración del principio de igualdad y sentencias que declaran la inconstitucionalidad sin nulidad (Ahumada Ruiz, 1991, pp. 169 y ss.).

La jurisprudencia alemana se ha manifestado en el sentido de que pueden ser objeto del recurso de queja constitucional las omisiones del legislador, sólo en el supuesto de que se trate de omisiones relativas, no admitiendo, por el contrario, aquel 
recurso contra las omisiones absolutas, es decir, contra la ausencia de la promulgación de una norma legal, al margen de cualquier otra discusión.

Para el caso argentino, Bidart Campos, en el caso concreto de la inaplicación de tratados internacionales, ha manifestado que como los tratados prevalecen sobre las leyes, el incumplimiento de un tratado por omisión legislativa se puede asimilar a una omisión inconstitucional (Bidart Campos, 1993, p. 160). En el caso brasileño la Constitución prevé el derecho de participación de los trabajadores en las ganancias y en la gestión de las empresas, conforme a lo definido en la ley (y ahora más con un obrero en la presidencia), pero, si ese derecho no se concreta por omisión del legislador en dictar la ley necesaria para la aplicación de la norma, tal omisión se caracterizará como inconstitucional. Al respecto, en el caso colombiano el profesor de la UPTC, Fabián López (2001), ha escrito un importante trabajo, en el que reclama la necesidad de reglamentar el art. 57 de la Constitución que dice: “La ley podrá establecer los estímulos y los medios para que los trabajadores participen en la gestión de las empresas".

Este autor presentó una acción de inconstitucionalidad por omisión ante la Corte Constitucional, la cual en sentencia C-745 de 1998 se declaró inhibida para pronunciarse, bajo el supuesto de no estar el instituto consagrado en nuestro ordenamiento. Considero de la mayor importancia tales argumentos para la propuesta presentada. En los primeros cinco años de decisión de la Corte Constitucional colombiana no se encuentran pronunciamientos sobre el tema de las omisiones legislativas inconstitucionales, abordadas sólo de forma indirecta en algunos de sus fallos, como en las sentencias C-108 y C-024 de 1994, C-070 de 1996 y C-109 de 1995, entre otras.

En la sentencia C-543 de 1996 con ponencia de Carlos Gaviria y aclaración de voto de los magistra- dos Eduardo Cifuentes, Alejandro Martínez y José Gregorio Hernández, la Corte fijó una posición con respecto a su competencia para el control abstracto de las omisiones legislativas inconstitucionales, cuyas premisas se han mantenido incólumes posteriormente. En la demanda que originó el pronunciamiento de la corporación se planteó la inconstitucionalidad legislativa por omisión derivada de la no expedición de las leyes que reglamentan las acciones de cumplimiento y las acciones populares, consagradas en los artículos 87 y 88 de la Carta. El actor solicitó a la Corte señalar un plazo razonable al Congreso para dar cumplimiento a tales preceptos constitucionales; de no cumplirse éste, disponer que el ejecutivo solicite facultades extraordinarias al Congreso, para que en el plazo establecido por el numeral 10 del art. 150 de la Carta, regule la materia. La Corte Constitucional definió la omisión legislativa como toda clase de abstención del legislador de disponer lo prescrito en la Constitución o la falta de actividad de éste en el cumplimiento de una obligación que le impone expresamente el constituyente.

También adoptó la clasificación doctrinaria de las omisiones inconstitucionales: absolutas, que se presentan cuando no se produce ningún precepto legislativo encaminado a ejecutar el deber concreto que le ha impuesto la Constitución: relativas, las que se producen en los siguientes supuestos:

- Cuando en cumplimiento del deber impuesto por la Constitución el legislador favorece a ciertos grupos perjudicando a otros.

- Cuando en desarrollo del mismo deber el Congreso en forma expresa o tácita excluye a un grupo de ciudadanos de los beneficios que le otorga al resto.

- Cuando el legislador, al regular o construir una institución, omite una condición o un ingrediente, que, de acuerdo con la Carta, sería exigencia esencial para armonizar con ella. 
En el mencionado fallo la Corte Colombiana determinó que las omisiones absolutas no hacen parte del ámbito de competencia de la justicia constitucional, con lo cual reconoce que el legislador tiene libertad de configuración frente a los preceptos constitucionales. La Corte presentó inicialmente los argumentos que se exponen en la doctrina para oponerse al control de las omisiones legislativas absolutas, por parte de los tribunales constitucionales:

- La inconstitucionalidad por omisión no está prevista en la Constitución y, por lo tanto, no existe acción encaminada a impugnar la inactividad del legislador.

- La Constitución no impone plazos para que el legislador pueda cumplir con su obligación de legislar. En consecuencia, mal podría sostenerse el incumplimiento de una obligación de hacer, si no se señala el tiempo en el que se debe realizar ésta; requisito que también es indispensable para determinar si la omisión es justificable o no.

- En las acciones de inconstitucionalidad lo que se controla es el texto mismo de la norma y si se está ante una omisión, existe un vacío de regulación, es decir, hay ausencia de texto.

- Si con ocasión de la omisión se violan derechos o libertades reconocidas por la Constitución, es ella la que contempla otras acciones para protegerlos.

- Si el órgano controlador de la Constitución ordena al Legislativo expedir una ley está atentando contra la autonomía e independencia de éste, pues sólo a éste le compete determinar el momento y la oportunidad de legislar:

Lo que se pretende mediante la acción de inconstitucionalidad, es evaluar si el legislador al actuar, ha vulnerado o no los distintos cánones que conforman la Constitución. Por esta razón, hay que excluir de esta forma de control el que se dirige a evaluar las omisiones legislativas absolutas: si no hay actuación, no hay acto qué comparar con las normas superiores; si no hay actuación, no hay acto que pueda ser sujeto de control.

Tal análisis condujo a la Corte a declararse inhibida para pronunciarse de fondo frente al caso objeto de la demanda. Por otra parte, es de resaltar en el estudio de la sentencia C-543 de 1996 la aclaración del voto de tres magistrados, quienes acertadamente -según nuestro concepto- se apartan de las consideraciones de la Corte, afirmando que ésta tiene actualmente la facultad de pronunciarse sobre las omisiones legislativas absolutas, la cual se desprende de la fuerza normativa de la Constitución como norma de normas.

La definición de Colombia como Estado Social de Derecho y la competencia de la Corporación para conocer de la constitucionalidad de las normas legales, a fin de garantizar la integridad y supremacía de la Carta (art. 241 ord. 4 C.P.). Para ellos la omisión legislativa no implica un vacío de regulación, sino una regulación diversa, pues en los ordenamientos jurídicos no existen vacíos normativos, ya que los principios y la actividad judicial se encargan de llenarlos en virtud de la plenitud hermética del derecho. Dicha plenitud plantea que en los órdenes jurídicos no existen lagunas mientras existen jueces (ver sentencia C-083 de 1995). Cuando el legislador no expide una normatividad sobre un tema, no significa que la materia deje de estar regulada, sino que la regulación es diferente a la que existiría de haber sido expedida la correspondiente legislación.

Por otra parte, los exhortos constitucionales se originaron en Alemania y España. Se trata de exhortar al órgano legislativo para que dé cumplimiento al deber de legislar en relación con normas constitucionales expresas. El tribunal constitucional colombiano hizo uso de tal recurso en sentencias C-024 de 1994 y C-473 de 1994 exhortando al legislador a expedir la ley que dé desarrollo al artículo 28 transitorio de la Carta y también al 56. 
En la sentencia C-024 de 1994 la Corte analizó la necesidad de que el legislador, en cumplimiento del mandato contenido en el art. 28 transitorio de la Constitución colombiana expida en un plazo razonable la ley que atribuya la competencia a las autoridades judiciales para el conocimiento de las contravenciones especiales sancionables con penas de arresto, cuyo conocimiento correspondía a las autoridades de policía.

En la sentencia C-473 de 1994 la Corte hace evidente la omisión del legislador e incorpora en la parte resolutiva del fallo un exhorto al Congreso, para que expida la ley que defina los servicios públicos esenciales con respecto a los cuales se restringe el derecho constitucional de huelga consagrado en el art. 56 de la Carta. Esta técnica procesal, sin efecto vinculante para el legislador, fue reiterada en sentencia T-348 de 1997 en la cual la Corte exhorta al legislador, para que defina el régimen mínimo de beneficios del sistema de seguridad social en salud de las personas afiliadas al Fondo Nacional de Prestaciones Sociales del Magisterio.

En sentencias C-146 de 1998 y C-745 del mismo año, la Corte nuevamente analiza el tema de las omisiones legislativas absolutas y se declara inhibida reiterando la tesis expuesta en la sentencia C-543 de 1994. En el primero de los fallos se revisa la omisión del legislador en la actualización del poder adquisitivo de las pensiones de jubilación de los trabajadores que se pensionaron con posterioridad a la Ley 4 de 1966 y antes de la Ley 100 de 1993. En el segundo se somete a estudio la omisión del legislador en la reglamentación del artículo 57 de la Carta Constitucional relativo a la participación de los trabajadores en la propiedad de las empresas. En la sentencia C-543 de 1994 la Corte admite plenamente su competencia para conocer de las omisiones legislativas relativas para proteger el derecho a la igualdad o el derecho de defensa.
En el fallo de constitucionalidad C-407 de 1998 la Corte precisa que la omisión legislativa relativa no está restringida a los derechos de igualdad y debido proceso, dado que la mención a estos derechos se realiza a manera de ejemplo y la presentación de la omisión legislativa relativa permite una interpretación amplia no limitada a casos relacionados con dichos derechos. Otros fallos que reiteran la posición de la Corte son: C-690 de 1996, C-146 de 1998 y C-067 de 1999.

La Corte Constitucional colombiana, igualmente, mediante la sentencia C-188 de 1996 señaló que el art. $2^{\circ}$ de la Carta fija los fines esenciales del Estado, los cuales imponen al órgano legislativo el deber de llevar a cabo, en un plazo razonable, las reformas y desarrollos legales necesarios para garantizar la efectividad de las decisiones del Constituyente. En esa misma forma insistió en la sentencia T-081 de 1993.

En la sentencia C-409 de 1997, sobre la extinción de dominio, expresó que el Legislador puede desconocer los deberes que la Constitución le impone en tres formas:

- Omisión legislativa absoluta: el Congreso no produce ningún precepto encaminado a ejecutar el deber constitucional.

- Omisión legislativa relativa: el Congreso cumple lo ordenado por la Carta, pero favoreciendo a ciertos grupos o perjudicando a otros, o excluyendo a algunos.

- Cuando se omite un ingrediente esencial y constitucional al regular una institución, la cual está previamente delimitado en la propia Carta.

La Corte manifestó entonces que el art. 241 de la Carta no autoriza a la máxima guardiana de la Constitución para pronunciarse sobre las omisiones absolutas, pues -según ella- "si no hay actua- 
ción, no hay norma que comparar con las normas superiores", mientras sí tiene competencia para pronunciarse sobre las relativas, como por ejemplo, cuando se violó el principio de igualdad o el debido proceso. Mediante sentencia C-451 de 1999 la Corte se declaró inhibida. Lo cierto es que la Corte fue poco audaz en la materia, como sí lo había sido en otras actuaciones, como cuando apeló a crear el mínimo vital, en un típico acto de activismo judicial para algunos, y de reconocimiento a los derechos de los más pobres, para otros. En conclusión, es exigible una reforma constitucional para incorporar el instituto frente a las omisiones absolutas y aún en torno a las relativas, para comprometer a la jurisprudencia futura si existiere una mutación eventual, que parte de la concepción ideológica de los magistrados (Silva García, 2002).

La Constitución de 1991 propicia un rompimiento con las categorías interpretativas clásicas, antes incuestionables, y se inscribe en una nueva hermenéutica encaminada hacia decisiones legales $y$ racionales, que se orientan a los principios y valores contenidos en la Carta Política. La Corte Constitucional, siguiendo la jurisprudencia de los principales tribunales europeos, ha entronizado en la teoría constitucional colombiana diversas modalidades de decisión: sentencias interpretativas o de rechazo, integradoras o aditivas, y más recientemente de constitucionalidad temporal, que determinan distintas maneras de remediar las omisiones del legislador contrarias al orden constitucional.

Para la Corte el proceso de control de constitucionalidad implica siempre un juicio relacional que busca determinar si una norma legal es o no conforme con las normas constitucionales; tal interpretación es obligatoria en la medida en que la Constitución tiene vigor normativo.

A través de la modalidad de sentencias integradoras la Corte incorpora en el orden jurídico los mandatos constitucionales, integrando su contenido normativo en la regulación legal, con lo cual llena los aparentes vacíos o hace frente a las inevitables indeterminaciones de ésta.

La Corte expone:

Si el juez para decidir un caso se encuentra con una indeterminación legal, ya sea porque el enunciado legal es insuficiente, ya sea porque el enunciado es contrario a la Carta, el juez debe proyectar los mandatos constitucionales directamente al caso, aun cuando de esa manera, en apariencia, adicione el orden legal con nuevos contenidos normativos (C-470-97).

En la sentencia C-109 del 95 la Corte aplica analógicamente a la hipótesis normativa prevista en el artículo 372 numeral 1 del Código Penal, que contempla la agravación del delito de hurto en cuantía superior a cien mil pesos, el art. 19 de la Ley 190 de 1995, que adopta el índice de salarios mínimos legales mensuales como factor de determinación de la cuantía para agravar la pena del delito de peculado para remediar la omisión legislativa en la actualización de la cuantía prevista en el año de 1980 reajustándola a 18,8 salarios mínimos legales mensuales.

Esta tesis de la Corte fue reiterada en la sentencia C-118 de 1996 para la actualización del inciso $2^{\circ} \mathrm{del}$ art. 357 del Decreto Ley 100 de 1980, que establecía que la pena del delito de emisión y transferencia ilegal de cheques se aumente máximo hasta en la mitad, si la cuantía del cheque es superior a cien mil pesos.

Las sentencias de exequibilidad temporal son otro buen ejemplo de innovación. En la sentencia C-221 de 1997 se utiliza la figura de la constitucionalidad temporal o de inexequibilidad diferida. En este fallo la Corte advierte la inconstitucionalidad del art. 233 del Decreto 1333 de 1986, que fija impuestos con respecto a recursos naturales no renovables, con ocasión de la omisión del legislador en cuanto a la imposición del pago de regalías 
en su explotación, como lo establece el art. 360 de la Carta; no obstante, mantiene la norma dentro del ordenamiento jurídico por un plazo de cinco años, a efectos de que el ente legislativo en el mismo tiempo profiera la norma respectiva.

La temporalidad en la decisión de exequibilidad permite que en un primer momento se confiera prevalencia a la libertad legislativa, pero de persistir la omisión se entenderá que con su silencio el Congreso ha renunciado a legislar la materia, por lo cual no es contrario al principio de separación de poderes, que ese régimen sea definido por la Corte Constitucional.

El ordenamiento constitucional de Brasil consagra el instituto del mandado de injuncao, como acción procesal independiente de la inconstitucionalidad por omisión, con importantes efectos frente a las omisiones. Esta acción faculta a la persona que se considere afectada en sus derechos por la ausencia de reglamentación normativa del precepto constitucional, para demandar ante el órgano omitente la viabilización de su derecho. Tal figura confiere inmediata aplicabilidad a la norma constitucional que consagra los derechos y prerrogativas lesionadas con la omisión.

La diferencia más importante entre la inconstitucionalidad por omisión y el mandado injuncao radica en que la primera es un control abstracto que pretende la salvaguarda de la Constitución y el segundo es un control para un caso concreto, en defensa de derechos individuales. Ahora bien, ambas figuras están orientadas al control de las omisiones inconstitucionales.

\section{OMISIÓN Y AFECTACIÓN DE DERECHOS FUNDAMENTALES}

Una distinción que puede ser relevante es la que diferencia las omisiones según su incidencia en los derechos fundamentales; esto Ileva a con- frontar las omisiones que afectan los Derechos Fundamentales y las omisiones que no los afectan. La trascendencia de las primeras es necesariamente mayor por el peso específico que los derechos fundamentales tienen en el concepto de Constitución, impuesto hoy en día en la doctrina. En efecto, una constitución no es un mero texto que lleva ese nombre, una simple hoja de papel subordinada a la voluntad de los gobernantes de turno, tal y como lo reprochaba Lasalle a sus coetáneos (1989, p. 119), sino que posee un contenido axiológico determinado, enlazando así las raíces revolucionarias del término con el art. 16 de la Declaración de los Derechos del Hombre y del Ciudadano de 1789 -toda sociedad en la cual la garantía de los derechos no esté asegurada, ni la separación de poderes determinada, no tiene Constitución.

A mayor abundamiento a la hora de señalar el papel determinante de los Derechos Fundamentales en la actualidad, cabe decir que la doctrina acerca de éstos se muestra como base funcional de la democracia (Häberle, 1994, p. 50).

\begin{abstract}
Por imperativo de las condiciones socioeconómicas, la mayor parte de los derechos fundamentales y libertades públicas requiere, para su efectividad, de la intervención de los poderes públicos, habiendo perdido nitidez la vieja distinción entre derechos de libertad y derechos de prestación [dado que] [...] casi todos los derechos y libertades tienen una dimensión prestacional difícilmente desvinculable de su ejercicio individual (Gómez Puente, 1997, p. 264)'.
\end{abstract}

La gravedad de este tipo de omisión queda subrayada en los denominados derechos de segunda y tercera generación que requieren como condición

1 El contenido esencial de los derechos es fuente de obligaciones legislativas: derecho a una medida legislativa concreta y derecho a una medida legislativa institucional (Gómez Puente, 1997, pp. 54 y ss.). 
sine qua non para su eficacia la interposición del legislador. En estos casos el "fraude" constitucional puede alcanzar cotas verdaderamente inaceptables, lo que chocaría con la acertada afirmación de Hans Meter Schneider (1979): “Difícilmente un Estado constitucional o cualquier otro orden social puede renunciar hoy a garantizar los derechos fundamentales". De ahí que se pueda decir que Ios Derechos Fundamentales vinculan al poder público en todo su comportamiento, en su hacer y dejar de hacer.

Un problema diferente, pero también relativo a los derechos fundamentales, es el no cumplimiento de las obligaciones de desarrollo que impone la normativa internacional de los derechos humanos. Es el caso de las exigencias procesales que recoge el art. 14.5 del Pacto Internacional de Derechos Civiles y Políticos.

Gomes Canotilho aportó el concepto de "Constitución dirigente", con el cual alude a un programa de actuación futura que tiene que ser llevado a cabo por los poderes constituidos y así llegar a una sociedad más avanzada bajo la inspiración del principio de igualdad material. Semejante planificación supone elevar la importancia de la estatalidad y reducir el margen o libertad de maniobra de los poderes públicos, si bien se impulsa su actuación, aunque por sendas prefijadas. La génesis del documento constitucional se sitúa en un contexto político-social, en el cual los hombres tienen determinadas expectativas frente a ciertos problemas y a ciertas posibilidades de acción.

La inconstitucionalidad por omisión aparece en este esquema como un poderoso instrumento, al menos en el campo político, para el desarrollo de esos planes preconcebidos y con objetivos establecidos. Tales posiciones son perfectamente compatibles con el rasgo de la normatividad de la Constitución, por lo que rechazan lo que generalmente se entiende por normas programáticas (principios políticos más que normas jurídicas vinculantes).
Los preceptos de la Carta Magna no son meros principios programáticos que "invitan" a los poderes públicos a una actuación determinada sin imponérsela. Por el contrario, los preceptos del Texto Superior son verdaderas normas jurídicas, aunque no todas de igual significación y trascendencia, que imponen comportamientos y modos de actuar de forma imperativa y no sujetos al arbitrio de la voluntad de los poderes constituidos, salvo que expresamente así lo prevea la misma disposición constitucional. Ello es especialmente palpable en aquellas normas que se traducen en obligaciones que sujetan a esos órganos de poder. No en vano todas las normas, ya sea inmediata o mediatamente, son la expresión de un mandato imperativo.

El gran peligro de no aceptar el instituto de la infracción de la Carta Magna por inactividad legislativa reside en que se abren las puertas al fraude constitucional, es decir, al engaño con el que se lesiona todo el espíritu del constituyente. Tal engaño al poder constituyente supone, en una correcta línea de pensamiento democrático, un atentado al pueblo detentador de la soberanía, en representación del cual actuó aquél poder. Los valores, aspiraciones y anhelos de los ciudadanos que fueron depositados en la Norma Básica pueden quedar reducidos a vagas ideologías o pensamientos altruistas plasmados en unas hijas de papel, mientras que la "Constitución real" caminaría por otro sendero. Esto es una burla, un despropósito constitucional.

Loewenstein afirma que:

[...] cada sociedad estatal, cualquiera que sea su estructura social, posee ciertas convicciones comúnmente compartidas y ciertas formas de conducta reconocidas que constituyen, en el sentido aristotélico de politeia, su "constitución". Consciente o inconscientemente, estas convicciones $y$ formas de conducta representan los principios sobre los que se basa la relación entre los detentadores y destinatarios del poder (Loewenstein, 1986, pp. 149-150). 
Estas convicciones del pueblo soberano recogidas por el poder constituyente no jugarían papel alguno si la inactividad impune del poder público, especialmente del órgano legislativo, cobrara tal dimensión que convirtiera en un espejismo o falacia el texto constitucional. Se erosiona la conciencia constitucional.

El mandado de injuncao brasileño, prescrito en el inciso LXXI del art. $5^{\circ}$ de la Constitución de Brasil de 1988, es una figura procesal garantista de los Derechos Fundamentales, que se concede siempre que la falta de norma reglamentaria impida el ejercicio de los derechos y libertades constitucionales y las prerrogativas inherentes a la nacionalidad, la soberanía y la ciudadanía. En este caso, para aplicar el instituto, se encuentra con una persona titular de derechos y libertades que no se pueden materializar por la ausencia de una reglamentación exigida o supuesta por la Constitución. La finalidad estriba en conferir inmediata aplicabilidad a la norma superior portadora de aquellos derechos $y$ libertades y que está en el "vacío" por la ausencia de reglamentación. Es clara la diferencia de esta figura con la inconstitucionalidad por omisión, pues ésta última regula el modo de hacer efectivo un precepto constitucional, mediante la determinación del Tribunal Constitucional para tal efecto, ordenando al Congreso que la cristalice, mientras el mandado no pretende la elaboración de las disposiciones reglamentarias, sino la realización del acto, para materializar el derecho abstracto.

\section{MUTACIÓN CONSTITUCIONAL}

La mayoría de las constituciones actuales son rígidas y se caracterizan por prever un mecanismo especial de reforma cuya dificultad es más exigente que la de un procedimiento de reformas de las normas ordinarias. Con este mecanismo se pretende compatibilizar la idea de supremacía constitucional con el principio democrático, ya que aquélla lleva a la fundamentalidad de la Ley
Fundamental y ésta a la imposición de la voluntad mayoritaria. Es así como surge la denominada reforma constitucional; en esa forma se conecta con la idea schmittiana de permanencia del poder constituyente. Por lo tanto, la reforma de la Constitución sólo podrá, en principio, tener lugar a través de este procedimiento que contempla la propia norma normarum. Cosa distinta es elaborar otra constitución, lo que hace entrar en escena la soberanía del nuevo poder constituyente.

Georg Jellinek distingue entre las nociones de reforma y mutación constitucional: "Por reforma de la Constitución entiendo la modificación que deja indemne su texto sin cambiarlo formalmente, que se produce por hechos que no tienen que ir acompañados por la intención, o conciencia de tal mutación" (1985, p. 7).

Así, entonces, se tiene que la inercia o la inactividad se puede convertir en una causa de reforma de la Carta magna al margen de cualquier tipo de legalidad constitucional. Una muy acusada inercia de los poderes constituidos en concretizar y desarrollar los valores y programas constitucionales puede provocar una alteración real de la Carta Magna, cuyos efectos seguramente serán intolerables desde una óptica jurídica.

Una gran discusión acaeció en Colombia con la reforma constitucional que aprobó la reelección inmediata presidencial, por cuanto algunos veían que se desconocían principios axiales de reglas del juego políticas tradicionalmente aceptadas en el país y que ponía a los opositores del Presidente en una condición de infravaloración al carecer del manejo de los factores reales del poder.

\section{El peso del Ejecutivo}

Es indudable el fortalecimiento del poder Ejecutivo en detrimento de la tridivisión de poderes. La aprobación en Colombia de la reelección inme- 
diata presidencial así lo demuestra. En el Derecho Constitucional fueron apareciendo nuevas figuras, como la legislación delegada, el Decreto-Ley o Decretos legislativos, usadas de forma abusiva en muchas ocasiones, parapetándose en cualificaciones técnicas y estados de urgencia manifiesta o de necesidad. La ley se convierte, además, en un concepto eminentemente formal alejado de toda materialidad, que en ocasiones va a regular casos particulares por lo que se utilizan expresiones como "leyes-medida" y similares. Vale la pena cuestionar si no prevalece la velocidad de la gestión administrativa, ante lo cual el parlamento queda con la competencia de aprobar leyes con amplios enunciados políticos pendientes de desarrollo posterior.

Asimismo, el creciente protagonismo de los Jefes de Gobierno o de Estado desplaza el centro de la confrontación política fuera de las sedes parlamentarias. Cuando las urnas o los pactos poselectorales así lo establecen, se producen sólidas mayorías parlamentario-gubernamentales, que convierten en incontestable la preeminencia del Ejecutivo, por lo tanto, se extiende por todos los poderes públicos con la consiguiente disfuncionalidad que aquello entraña.

La inexistencia de la figura de la inconstitucionalidad por omisión legislativa incide en el fortalecimiento del Ejecutivo, al no presionar al Parlamento con el objeto de que se emane la normativa de desarrollo necesaria. Lo que tenía que ser actividad del poder legislativo se traslada al Ejecutivo. De esta forma, el Ejecutivo se ve con mayor libertad de movimientos ante la inactividad impune del órgano legislativo, por lo que puede llevar a cabo su programa de actuación, que es posible que esté guiado más por intereses electorales que por el contenido de la Carta Magna y sus exigencias transformadoras.

Es necesario desarrollar una menor proyección del Ejecutivo con base en pautas de legitimación del Estado democrático y en el cumplimiento de las funciones que constitucionalmente se le asignan, de una manera general y que deben concebir al Congreso con un carácter preeminente. El equilibrio de la división de poderes tiene que seguir siendo una aspiración nunca acabada, porque el equilibrio en la distribución del poder forma parte de lo que debe ser una organización política ideal. La participación del pueblo en el poder cumple una de las aspiraciones más caras de la democracia. Esto obliga a intentar que el cuerpo legislativo, que asume una clara función legitimadora, no pierda el protagonismo que debe tener en la realización de los encargos constitucionales que activen el proyecto contenido en la Carta Fundamental. La defensa de la inconstitucionalidad por omisión ayuda a ello.

El principio de separación de poderes y el de colaboración armónica entra en discusión. En el Estado social de Derecho estos principios resultan legitimados en virtud de la unidad en los fines estatales que hace necesario que los órganos públicos realicen los mismos valores para el mantenimiento de un Estado de Derecho garante de las libertades fundamentales de los individuos.

En sentencia C-212 de 1994, la Corte Constitucional definió el alcance del postulado contenido en el inciso segundo del art. 113 de la Carta colombiana:

Ninguna función pública encuentra en sí misma su fundamento. Todas ellas se justifican en razón de los fines que persigue la organización estatal, entre los cuales cabe destacar los esenciales indicados en el art. 2 de la Constitución [...] Los órganos del Estado tienen funciones separadas pero colaboran armónicamente para la realización de sus fines, con lo cual elimina todo criterio absoluto en cuya virtud cada rama u órgano tenga que actuar forzosamente dentro de marcos exclusivos, rígidos e impermeables. Se trata, más bien, de lograr un equilibrio que impida la concentración y el abuso del poder pero que a la vez permita, en 
virtud de una razonable flexibilidad, conjugar los esfuerzos de quienes lo ejercen con miras al logro de las metas comunes².

\section{AMINORACIÓN DEL CARÁCTER NORMATIVO DE LA CARTA}

El control de la inconstitucionalidad por omisión descansa sobre el principio de supremacía normativa de la Constitución, uno de cuyos postulados propugna la sujeción a ésta del legislador y demás órganos del poder público. La teoría constitucional moderna reconoce a la Constitución como norma jurídica de aplicación directa, fuente formal y material de todo el sistema normativo (García de Enerría, 1981).

La negativa a aceptar la verdadera infracción de la Ley Básica por omisión legislativa se erige en una desvalorización del carácter normativo de la misma. Y es que los preceptos constitucionales -como ya se ha dicho- son auténticas normas jurídicas, con una relevancia distinta por el mismo hecho de ser constitucionales, pero que no pierden ese carácter normativo.

Ese carácter normativo reclama un tratamiento represor de las vulneraciones que sufre el texto de la Constitución. Estas vulneraciones son igualmente graves por acción que por omisión, es decir, por un facere o actuación positiva que por un non facere o inactividad. Negar y desconocer esta segunda manera de mostrar las infracciones a la Lex Superior es tender hacia la negación del carácter normativo de la misma y hacia la afirmación de su condición de texto programático que no vincula a los poderes constituidos, concepción que rechazamos de plano en las actuales ramas de la ciencia jurídica del Derecho Constitucional y de la Teoría de la Constitución.

2 Se pueden ver otras sentencias sobre el particular: C-497 y C-592 de 1995, C-310 de 1996, C-283 de 1995 y C-229 de 1995.
El derecho nace para cumplirse, para tener vigencia e integrarse en el devenir de la vida cotidiana. La Constitución forma parte del Derecho. La plenitud del Estado de Derecho no se agota en la sola existencia de una adecuada y justa estructura normativa general, sino que exige esencialmente la vigencia real y segura del Derecho en el seno de la comunidad y, por ende, la posibilidad de hacer efectiva la justiciabilidad plena de las transgresiones a la ley y a los conflictos jurídicos. El valor del Derecho radica en la posibilidad de su realización práctica. Esto se relaciona con la idea de que la función del derecho, en general es la de realizarse; lo que no es realizable, no podrá ser derecho, pues pierde la eficacia.

La reglamentación del régimen jurídico que desarrolle la omisión debe poseer dosis de flexibilidad para hacer frente al elemento esencial del concepto de inconstitucionalidad por omisión que es el paso de un tiempo excesivamente largo desde la promulgación de la Carta Magna. Las opciones son diferentes en función del sistema de control de constitucionalidad que exista en el ordenamiento en cuestión. De un sistema concentrado a uno difuso la variación parece que tiene que ser grande. La Corte Constitucional o los Tribunales Constitucionales son los llamados a dar la solución a la casuística que se presente.

En líneas generales, se puede hablar de tres grandes formas que tendría el órgano de justicia constitucional para resolver la problemática. Una sería dictando la norma legal que exige el encargo constitucional, teniendo tal norma una vigencia que tocaría a su fin cuando el órgano legislativo emane la disposición a la que se encuentra obligado por ese precepto constitucional incompleto. Esta solución pone más que en entredicho la separación de poderes y el reparto de funciones actualmente existente en los organigramas estatales. Otra vía consistiría en que el Alto Tribunal ordenara el dictado de la ley de desarrollo constitucional. Una 
variante de esta solución sería la recomendación al legislador en el sentido de mostrarle la conveniencia de dictarla. En tercer y último lugar, el Tribunal podría solucionar el caso concreto de acuerdo con las previsiones constitucionales, integrando la laguna si ésta existiera. Esta última solución es acumulable a la anterior.

\section{¿EXISTE EL DERECHO A LA LEGISLACIÓN OPORTUNA?}

Las normas constitucionales de eficacia limitada que contienen encargos concretos de desarrollo legislativo ulterior hacen nacer una obligación que pesa sobre el poder legislativo; consiste en la emanación de tal ley de desarrollo del precepto constitucional. De esta forma, junto al deber global de legislar se tiene un deber concreto originado en determinado precepto constitucional que requiere un complemento posterior.

La imposibilidad de que la Ley Básica, por sus mismas funciones y caracteres, no pueda agotar todas las instituciones que recoge, hace imprescindible la actuación el poder legislativo. Se suele distinguir entre deber y obligación, el primero más genérico y el segundo más concreto. Existe el derecho a la tutela judicial efectiva.

García de Enterría ha distinguido, en las situaciones jurídicas pasivas, entre sujeciones, deberes y obligaciones. En la genérica categoría de los poderes jurídicos, entre potestad, derecho subjetivo e interés legítimo. A su vez, establece relación entre potestad y sujeción, ya que ésta supone la eventualidad de soportar los efectos de una potestad de otro; $y$ también entre derecho subjetivo y obligación, puesto que la obligación está en estricta correlación con un derecho subjetivo de otro sujeto, sujeto que es parte de la relación y que tiene el poder de exigir el cumplimiento del comportamiento previsto (García de Enterría, 1990, pp. 28 y ss.).
En torno a estas reflexiones surge una pregunta de gran importancia: ¿a la obligación de desarrollo constitucional que sujeta al Poder Legislativo le corresponde un derecho subjetivo del ciudadano a la legislación, es decir, un derecho que le permita exigir la emanación de una ley a la que constitucionalmente se halla obligado el legislador? Si ello es así, no cabe duda de que ese derecho subjetivo exige el complemento de mecanismos procesales de garantía.

La figura del derecho privado, que procede del campo del Derecho Privado, significa la existencia de un poder ostentado por el titular de ese derecho subjetivo con el cual puede imponer obligaciones o deberes a otros sujetos. La garantía de tal posición reclama la necesaria tutela judicial. Con esta base nació la doctrina de los derechos públicos subjetivos en Alemania e Italia. Eran los derechos de todo ciudadano frente al Estado, que era el ente que despertaba desconfianza, porque los podía transgredir. Hoy en día se considera que hay un fundamento ético de los derechos públicos subjetivos en la medida en que se relacionan con Ios derechos fundamentales. La necesidad de defensa de los derechos de los ciudadanos lleva a postular una institucionalización de formas democráticas (acciones populares, iniciativa popular, peticiones colectivas) que refuercen la protección contra omisiones inconstitucionales.

El tema de la obligación de legislar está abierto a permanentes conceptualizaciones y complementaciones, siendo necesario construir nuevas perspectivas y postulados para analizar la procedencia de las pretensiones del ciudadano que se vea perjudicado por la ausencia de normativa de desarrollo constitucional. En la mayor parte de los ordenamientos no existe positivizado el derecho a la legislación, pese a los méritos de una institución de tal naturaleza. De esta forma no existe acción para articular la defensa de semejante derecho. Por lo tanto, se está ante un deber-obligación de legislar que no se corresponde 
con ningún derecho al dictado de normativa de desarrollo constitucional. Pero aun dentro de ese deber-obligación de legislar habría que distinguir uno de carácter general que incumbe al legislador por ser tal, y uno de carácter especial o particular, que emana del concepto encargo constitucional que supone la norma incompleta.

Existen silencios legislativos que son constitucionales en el sentido en que no crean situaciones jurídicas contrarias a la Constitución, bien porque ésta dejó a la voluntad política la regulación o bien porque la norma constitucional es siempre susceptible de aplicación directa y, por ende, la tarea legislativa está limitada a definir elementos no esenciales del supuesto normativo.

La primera hipótesis se encuentra frente a disposiciones que se positivizan bajo una fórmula potestativa. Tal es el caso, para algunos, del artículo 57 de la Constitución colombiana: “La ley podrá establecer los estímulos y los medios para que los trabajadores participen en la gestión de las empresas". Casos "potestativos" podríamos encontrar en los artículos siguientes de la Carta Colombiana:

- Veintiséis: la ley podrá exigir títulos de idoneidad (a las profesiones y oficios). La ley podrá asignarles funciones públicas y establecer los debidos controles (a los colegios profesionales).

- Treinta y siete: sólo la ley podrá establecer de manera expresa los casos en los cuales se podrá limitar el ejercicio de este derecho (de reunión y manifestación).

- Ciento ocho: la ley podrá establecer requisitos para garantizar la seriedad de las inscripciones de candidatos.

- Ciento nueve: la ley podrá limitar el monto de los gastos en las campañas electorales.

En estos casos el silencio legislativo tiene una aceptación constitucional y resulta difícil el control jurídico, aunque el político sí cabe. La omisión es inconstitucional cuando está referida a normas imperativas frente a las cuales no puede discrecionalmente disponer en el tiempo. Tampoco existe la omisión legislativa en los casos de normas con eficacia directa, como los derechos fundamentales con vigencia inmediata. El artículo 53.1 de la Carta Española, el $1^{\circ}$ de la Alemana y el art. 85 de la Lex Legum colombiana son claros ejemplos.

El llamado reconocimiento del carácter normativo de la Constitución deriva en la aplicabilidad directa de los preceptos superiores, de ahí que de toda norma constitucional se pueda derivar un contenido -así sea mínimo- de eficacia y vinculatoriedad directa. En ese sentido, se cree que existe un derecho subjetivo a la norma o a la legislación.

Es preciso no olvidar que el propio Kelsen acepta la posibilidad de vulnerar la Constitución por omisión:

\section{La "violación" de la Constitución significa la verificación de un hecho que contradice a la Constitución, sea por acción, sea por omisión; esto último se da sólo cuando se trata del incumplimiento de una obliga- ción y no de una falta de reconocimiento de un derecho concedido por un órgano de la Constitución (Kelsen, 1995, p. 3).}

\section{LA ACCIÓN CONCRETA DE INEXEQUIBILIDAD POR OMISIÓN}

La forma más precisa de protección del instituto de la inconstitucionalidad por omisión y que, a la vez, proporciona -al menos teóricamente- mayor eficacia es la elección de una acción directa ciudadana, presentada ante el órgano de justicia constitucional que tenga tal competencia. Los requisitos de admisión tienen que hacer constar que se trata de la vulneración de una concreta obligación de desarrollo, esta última proviene de una norma específica constitucional, por consiguiente, es una vulneración tanto absoluta como relativa, esta última en el sentido de legislación de desarrollo 
parcial que no otorga la eficacia que reclama el precepto de la Norma Básica. Igualmente, tiene que haber transcurrido un tiempo demasiado largo desde la promulgación de la Ley de Leyes, salvo que el precepto constitucional vulnerado prevea expresamente un término para el dictado de la legislación de desarrollo, en cuyo caso se debe admitir la acción pasado ese periodo.

La legitimación activa es la misma que se señala para plantear la acción de inexequibilidad contra normas con rango de ley. Por lo tanto, la inactividad legislativa tiene que ser superada desde la Corte Constitucional, instando vinculantemente al Legislativo, pues de lo contrario es innane cualquier recomendación, salvo los efectos políticos que eventualmente acarrea su desatención.

También es posible la inquietud sobre omisiones parciales o relativas; en este caso el tratamiento puede ser distinto al de las omisiones absolutas. Para el análisis de un juez y si en su labor interpretativa del ordenamiento detecta una omisión inconstitucional puede aplicar directamente el precepto constitucional no desarrollado, si fuere permitido, pero no puede reemplazar al Legislativo en la "creación" de la norma por el desconocimiento que entrañaría frente a la separación de los poderes públicos.

Frente a la acción de defensa de los derechos fundamentales, basada en la inconstitucionalidad por omisión vulnerada por una omisión relativa, la jurisprudencia es la encargada de realizar la interpretación correspondiente. La legitimación activa está en manos de aquel individuo o grupo que se ve excluido de una normativa concreta, con la consiguiente vulneración del principio de igualdad. En términos generales, la sentencia estimatoria tiene que reponer los efectos de la vulneración, sin embargo, la norma debe atender a ese individuo o grupo que no es considerado por ella. De esta forma se resuelve el caso concreto.
Supuestos distintos a esta protección de la igualdad son los casos de la vulneración de un derecho fundamental por omisión absoluta de las medidas legislativas necesarias para dotarles de eficacia. Se cree que el sujeto lesionado tiene que ostentar legitimación para recurrir en un caso así; la sentencia tiene que resolver el caso concreto, a través de la directa aplicación del derecho fundamental, de esta forma, colma la laguna existente en una cuestión como ésta, que posee máxima relevancia jurídica. No se puede olvidar que los derechos fundamentales son fin en sí mismos y expresión de la dignidad humana. Son simultáneamente la condición sin la que no podría operar el Estado constitucional democrático, puesto que no pueden dejar de ser materializados sin que peligre la forma de Estado.

\section{CARACTERÍSTICAS PRIMORDIALES DE LA FIGURA}

Doctrinariamente existen varios conceptos para desarrollar este instituto. Para Gomes Canotilho la omisión legislativa inconstitucional es el incumplimiento de mandatos inconstitucionales permanentes y concretos (1987, p. 829). Por su parte, Francisco Fernández Segado la define como la inacción de una obligación constitucionalmente contemplada de legislar una determinada materia para que la norma constitucional tenga eficacia plena (1997, p. 25).

El Estado Social de Derecho exige la construcción de institutos que den respuesta eficaz a la compleja y rica realidad de nuestro tiempo. Uno de los principales desafíos es la construcción de la inconstitucionalidad por omisión, pese a que la doctrina, en general, no le ha prestado mucha atención. En el presente artículo, la inercia vulneradora de la Lex Legum se considera como la falta de desarrollo por parte del poder legislativo, durante un tiempo excesivamente largo, de aquellas normas constitucionales de obligatorio y concreto desarrollo, de forma tal que se impide su eficaz aplicación. 
Se tiene una actividad bifronte: por un lado, una inactividad y, por otro, una inconstitucionalidad.

La idea de inconstitucionalidad parte de reconocer varios factores causales como que las normas constitucionales son de obligatorio y concreto desarrollo, el tiempo transcurrido sin que ésta se produzca y la ausencia de verdadera eficacia del precepto de la Ley Fundamental. El carácter normativo de la Carta Magna, su supremacía, la vinculatoriedad de la obra del poder constituyente, la función transformadora que entrañan hoy en día los textos constitucionales y la existencia de un determinado tipo de normas en la Constitución (los Ilamados encargos al Legislador) son argumentos jurídicos poderosos para defender la introducción en un ordenamiento de la vulneración de la Norma Superior por omisión.

En los textos constitucionales existe un tipo de normas, denominadas encargos al legislador, enmarcables dentro de las que se denomina de eficacia limitada (normas incompletas o incluso en blanco), que se presentan como exigencias auténticas para el Poder Legislativo, al entrañar verdaderas obligaciones jurídicas de desarrollo ulterior. Sólo con el instituto defendido se les puede otorgar la eficacia o complitud que requieren.

Un encargo al legislador es una norma constitucional de eficacia limitada, que resulta de obligatorio y concreto desarrollo para que cobre eficacia plena, dada la previsión explícita o implícita en ella contendida. El Legislador no tiene libertad para exonerarse de su responsabilidad de desarrollo legislativo de la norma constitucional, que debe cumplir los límites constitucionales tratando de maximizar el espíritu del Constituyente y del Legislador es libre para decidir el momento en el que debe actuar, sin dilatarse sine die, de tal forma que enerve el contenido de dicha obligación.

Cuestiones económicas, políticas y de otra naturaleza, relacionadas en especial con los Derechos
Económicos y Sociales, deben estar presentes en el momento de revisar una posible inactividad legislativa. En este factor se reconoce un atenuante del vigor del instituto. Existe un debate sobre si existe o no un derecho ciudadano a la legislación, en el presente artículo se prefiere una respuesta positiva dentro del marco de un Estado Social de Derecho y sus postulados básicos.

Más allá que las simples sentencias que recomiendan al Legislador subsanar su omisión, se considera que debe existir un nivel de coerción básico que haga respetar el instituto. Siempre tiene que ser posible la reclamación en algunos supuestos de omisiones absolutas o relativas, que afecten los derechos fundamentales y al principio de igualdad, esenciales, ambos, en un sistema democrático.

Existen numerosas disposiciones constitucionales en la Carta colombiana, que no han sido reglamentadas y que ameritan un examen: derecho de petición frente a particulares, Estatuto del Trabajo, Ley Orgánica de Ordenamiento Territorial, distribución de la ganancia de las empresas para trabajadores, derecho de huelga, etc. A pesar de que no está reglamentada la figura de la inconstitucionalidad por omisión en Colombia, es menester señalar -más adelante- una serie de ejemplos en los cuales la Corte Constitucional ha incidido frente a las lagunas $y$ ha permeado al Legislador de forma positiva.

El instituto conlleva el reconocimiento de la Constitución como norma y su eficacia, consistente en ser cumplida y aplicada. Por el contrario, resultaría innane la figura. La adecuada garantía de los derechos humanos y la realización progresiva de la Carta exige del Derecho Constitucional la puesta en marcha de mecanismos que como la inconstitucionalidad por omisión superen el anquilosamiento en que se puede convertir la Norma Normarum. Se podrían sintetizar en tres aspectos las características de la omisión legislativa: 
- Una quiescencia o silencio del poder legislativo.

- La imperatividad constitucional de legislación, no general y abstracto, sino concreto.

- La generación de consecuencias inconstitucionales.

\section{INCONSTITUCIONALIDAD POR OMISIÓN E INEXEQUIBILIDAD}

Es clara la diferencia entre la inconstitucionalidad por omisión y la inexequibilidad tradicionalmente aplicada. La inconstitucionalidad por violación de la Ley Fundamental tiene un carácter positivo; en este caso existió una acción legislativa; entre tanto, la inconstitucionalidad por omisión tiene un carácter negativo, pues surge de la inacción, puesto que es la omisión de la obligación constitucional contemplada la que provoca el vicio.

Los enemigos del instituto apelan al principio de discrecionalidad del Legislativo, a la imposibilidad del activismo judicial y hasta al carácter antidemocrático de la judicatura. La inconstitucionalidad por omisión se define como la falta de desarrollo por parte del poder legislativo, durante un tiempo excesivamente largo, de aquellas normas constitucionales de obligatorio desarrollo, de forma tal que se impide su eficaz aplicación.

Para Jorge Miranda (1977) -Profesor de la Universidad de Lisboa-: "la inconstitucionalidad se verifica desde que los órganos del poder, por acción o por omisión, dejan de respetar los imperativos de la Constitución a la cual están adscritos". También se podría, jugando a la sinonimia, hablar de responsabilidad del poder legislativo por preterición, negligencia, inercia, inacción, dejación, resistencia, inactividad, indolencia, abstención, quiescencia. En general, sería la vulneración del ordenamiento jurídico a causa de un dejar hacer por parte de quien está obligado a actuar.
En Derecho penal existen delitos omisivos, como la omisión del deber de socorro o el prevaricato por omisión. La inconstitucionalidad por omisión se la ha definido como la falta de desarrollo por parte del poder legislativo, durante un tiempo excesivamente largo, de aquellas normas constitucionales de obligatorio desarrollo, de forma tal que se impide su eficaz aplicación. Para el iuspublicista Gomes Canotilho será el "incumplimiento de mandatos permanentes y concretos" (1987, p. 829).

Muchas veces existen normas de las llamadas "programáticas", cuya materialización se tarda años en desarrollar el poder legislativo, a veces a causa de la responsabilidad del Ejecutivo que debe afrontar las urgencias del día a día frente a enormes déficit presupuestales. Temas como el de la seguridad social, las pensiones adeudadas para la tercera edad, la defensa de los consumidores y usuarios, los servicios públicos, entre otros, muchas veces no hacen parte de la agenda del Ejecutivo de turno, que tiene otras veleidades. Aquí entraría la panoplia de Derechos Económicos y Sociales.

La inconstitucionalidad por omisión también podría operar amparando las normas finalistas que contienen mandatos abstractos: igualdad, derecho de participación democrática, etc. También es viable asemejar a la inconstitucionalidad por omisión con el denominado "estado de cosas inconstitucional" que la Corte Constitucional colombiana ha establecido jurisprudencialmente cuando encuentra que alguno de los poderes públicos, o varios, no han dado cumplimiento fáctico a órdenes constitucionales o jurisprudenciales, como es el caso del hacinamiento en las cárceles y que en los últimos años se ha tratado de paliar con ayuda norteamericana concretamente del "buró" de prisiones de Ios EE.UU. 


\section{INEFICACIA CONSTITUCIONAL}

Es importante recalcar en el disvalor que representa la ineficacia constitucional. Una situación de ineficacia constitucional es ciertamente censurable desde el ángulo en que se observe. La ineficacia deriva en un quebrantamiento de la cualidad de norma jurídica de los preceptos constitucionales, dada la inanidad en que la preceptiva queda para el mundo jurídico. Se hace evidente, entonces, el "fraude" legislativo.

Es pertinente establecer la conducta de hacer, en una eventual reglamentación del instituto, para que la figura tenga relevancia jurídica y así la omisión lesione el precepto. La omisión entonces pasa de un "no hacer nada" a un "no hacer algo" -como dice Stahler-, siendo ese algo lo que espera el orden jurídico. La filosofía del Derecho ha desarrollado muy bien el tema de la validez y la eficacia en el Derecho y particularmente me permito remitirlos al libro de Kaufmann (1999), traducido por el maestro Luis Villar Borda. Una norma puede ser válida pero no eficaz; para un sector de la doctrina existen normas programáticas, cuya validez es plena, pero que mientras no se desarrollen no producen efecto alguno, siendo inaplicadas por los operadores.

Por otra parte, como lo vimos con el art. 85 de nuestra Constitución, hay normas con eficacia plena per se, apelando a los principios, valores y normas marco. Esto se ha visto así: cuatro elementos característicos de la inconstitucionalidad por omisión:

- Inactividad del Legislador.

- El paso del tiempo generador del fraude.

- Exigencia constitucional de actuar.

- La ineficacia.

Sin embargo, es bueno precisar que pueden existir omisiones legislativas que no sean omisiones constitucionales. Ese aspecto es pertinente incor- porarlo en la reglamentación. Sobre el tiempo para que opere el instituto hay que observar las circunstancias y el contexto sociopolítico, especialmente en un sistema multipartidista.

\section{OMISIÓN Y LAGUNA}

El tema lleva a mirar también la figura de la laguna, pues el ordenamiento debe tener unidad y coherencia, no lagunas. La plenitud jurídica se opone a la laguna; lo no regulado significa que está permitido o que no es obligatorio, dentro de la rigidez de la lógica formal. La laguna se refiere más a situaciones imprevistas, mientras que la omisión entra en las situaciones previstas; la omisión es producto del incumplimiento de una obligación, no ocurre así con la laguna. Las omisiones son siempre el resultado de una voluntad omisiva, las lagunas son generalmente involuntarias. La sentencia que aborda una laguna complementa el ordenamiento, mientras la sentencia que declara la inconstitucionalidad por omisión puede originar una laguna, como dice Mortati.

Para el caso colombiano es bueno aclarar que la inconstitucionalidad por omisión no tiene relación con la figura estatuida en el Derecho Administrativo del silencio administrativo o negativo, pues jurídicamente parten de dos troncos distintos. Igual ocurre con la acción de cumplimiento regulada por la Ley 393 de 1997, cuyo objeto es el que toda persona pueda acudir ante la autoridad judicial definida en esta ley para hacer efectivo el cumplimiento de normas aplicables con fuerza material de ley o actos administrativos.

Se recoge la tradición rousseauniana, en la cual la ley es la expresión de la voluntad general y el legislativo tiene responsabilidades jurídicas derivadas de sus actos políticos. El art. $6^{\circ}$ de nuestra Carta reza que los servidores públicos son responsables por infringir la Constitución y las leyes, bien sea por omisión o extralimitación en el ejercicio de sus 
funciones. Si el Ejecutivo es el responsable por inercia, algunos hablan de ilegalidad por omisión, cuando la ley prevé la emisión de un reglamento o de un acto administrativo, mas no es el caso de un reglamento constitucional, en el cual también tendría posibilidad de ser accionado.

Los llamados principios éticos del Derecho -planteados por Heller en su monumental obra- si bien no tienen un desarrollo directo o exigible, ofrecen el marco de las reglas interpretativas para la decisión judicial y orientan el contenido en el cual se debe regir la expedición legal. No son normas adorno o maquillaje. Otra cosa es la anomia constitucional, tema que por razones de obedecer al ámbito de la sociología jurídica no se va a tratar en este artículo.

\section{CLASES DE OMISIÓN}

La omisión de un acto político, si no es obligatorio jurídicamente, no comporta una inconstitucionalidad por omisión. Hay dos clases de omisiones: omisión absoluta o total y omisión relativa o parcial.

La omisión total se refiere a la ausencia total de desarrollo de un precepto constitucional, lo cual indica que falta de manera absoluta la disposición que dé desarrollo legislativo al precepto constitucional. Por su parte, la relativa se refiere a la violación del principio de igualdad por olvido de ciertos grupos en la legislación o de situaciones que también debía regular y que crean o conservan una situación inconstitucional.

Otra omisión que se puede entender relevante es la que diferencia las omisiones que afectan a derechos fundamentales y las omisiones que no afectan a tales derechos. Como dijo Lasalle, una Constitución no es una simple hoja de papel, subordinada a la voluntad de los gobernantes de turno, sino que posee un carácter axiológico determinado, enlazando así con el art. 16 de la Declaración de los Derechos del Hombre y del
Ciudadano de 1789: toda sociedad que no asegure los derechos de sus ciudadanos ni la separación de los poderes públicos no tiene Constitución. Actualmente, los derechos fundamentales son la base de la legitimidad, la gobernabilidad y en últimas de la democracia. Como señala Gómez Puente:

\begin{abstract}
Por imperativo de las condiciones socioeconómicas, la mayor parte de los derechos fundamentales y libertades públicas requieren, para su efectividad, de la intervención de los poderes públicos, habiendo perdido nitidez la vieja distinción entre derechos de libertad y derechos de prestación [...] [dado que] casi todos los derechos y libertades tienen una dimensión prestacional o institucional difícilmente desvinculable de su ejercicio individual (Gómez Puente, 1997, p. 264).
\end{abstract}

El contenido esencial de los derechos es fuente de obligaciones legislativas: derecho a una medida legislativa concreta y derecho a una medida legislativa institucional. En cuanto a la inexistencia del texto legislativo como óbice del control de las omisiones legislativas inconstitucionales la doctrina coincide en que en ellas se revisan los efectos normativos producidos por el silencio. Por lo tanto, el objeto del control jurídico es la norma implícita que emana del silencio del legislador, esto es, la forma en que se regula la situación ante la ausencia de norma.

\section{ASPECTOS PROCESALES}

El tema da para hablar de omisiones evitables e inevitables, estas últimas son imponderables, que podrían disculpar o justificar un no actuar que debe ser justificado, pero que corresponde a una materia de la ciencia política. Como fruto del encargo constitucional al legislador, surge la necesidad funcional para éste de concretar las normas constitucionales para su complitud. Como dijo Stern: "Todas las normas de la Constitución son normas jurídicas vinculantes". Hay una conexión directa entre la idea de encargo constitucional y la obli- 
gación de legislar. La legislación no es solamente ejecución de la Carta, sino también su desarrollo. La Norma Normarum exige la construcción de un Estado Social. La inconstitucionalidad por omisión sería garantía de las garantías sociales. La Lex Legum colombiana habla de dignidad humana apuntando hacia el logro de un orden social justo. Los derechos sociales son derechos constitucionales y suponen obligaciones; de no cumplirse estas normas, se incurre en un fraude del poder constituido frente al constituyente.

Por otra parte, la inercia o parálisis legislativa puede Ilevar a una mutación constitucional -como dice Jellinek- sobre lo cual se una hace breve reflexión, aunque sí resulta preocupante el decaimiento o desvalorización del carácter normativo de la Carta. Es necesario no olvidar que los ciudadanos y los poderes públicos estamos sujetos a la Constitución.

La sanción opera sobre la conducta omisiva. También se sabe que la responsabilidad política, desde otra óptica, se vería seriamente lesionada, teniendo el elector en sus manos el instrumento del sufragio para la revocatoria. Detengámonos en los requisitos de admisión de la acción; la forma más clara de protección del instituto de la inconstitucionalidad por omisión y que a la vez proporcione, al menos en el plano teórico, mayor eficacia, sería la presencia de una acción directa ciudadana residenciable ante la Corte Constitucional que tuviera por objeto el estudio de tal omisión. Los requisitos de admisión tienen que hacer constar que se trata de la vulneración de una concreta obligación de desarrollo proveniente de una norma constitucional específica, vulneración tanto absoluta como relativa, esta última en el sentido de legislación de desarrollo parcial que no otorga la eficacia que reclama el precepto de la Norma Básica. Asimismo, tiene que haber transcurrido un tiempo largo -por definir- desde la promulgación de la Carta Magna, salvo que el precepto constitucional vulnerado prevea expresamente un término para el dictado de la legislación de desarrollo, en cuyo caso se debe admitir la acción pasado ese periodo.

La Corte Constitucional será la llamada a dar la solución a la problemática que se presente. De igual forma, ésta en su fallo podrá resolver en tres sentidos distintos:

- Dictando la norma omitida.

- Ordenar que el Congreso en un término prudencial dicte la Ley omitida.

- Recomendar la expedición de la Ley al órgano competente.

Lo cierto es que la primera fórmula vulnera la tridivisión de poderes, mientras que el $2^{\circ}$ o el $3^{\circ}$-apoyado con mecanismos coercitivos (por ejemplo: un proceso disciplinario o penal por prevaricato por omisión) podría obligar a superar el fraude del Legislador. $\mathrm{Si}$ la omisión es parcial, también opera, por ejemplo, en los derechos sociales que afecten el derecho a la igualdad de una persona o grupo social.

Otros recursos en los que se podría pensar frente a la quiescencia son el de la indemnización -como sucede en la Provincia Federal de Río Negro en la Argentina-, iniciativa popular legislativa, acciones populares, etc.

Es necesario detenerse a señalar que frente a la aplicabilidad existen dos clasificaciones: la primera, normas constitucionales inmediatamente aplicables y segunda, normas constitucionales de aplicación mediata. Las normas constitucionales de eficacia plena son de aplicabilidad inmediata. En cambio, las de eficacia limitada pueden ser de aplicación inmediata o mediata.

\section{CONCLUSIÓN}

Con base en el análisis anterior, me permito insistir en la necesidad de consagrar la inconstitucionalidad por omisión en Colombia como factor 
garantista de los Derechos Humanos. Creo que el debate del referendo en el Congreso abarcó temas insustanciales y ya debatidos en el pasado como la penalización de la dosis mínima de alucinógenos, o la congelación salarial para los ingresos superiores a dos salarios mínimos, o la prórroga ilegítima de los periodos de mandatarios locales y regionales, o la escalada impositiva a las verduras y las frutas, y el debate actual se debería preocupar por temas de mayor entidad que como el instituto de la inconstitucionalidad por omisión garanticen la verdadera eficacia de nuestra Carta Magna.

La introducción de la inconstitucionalidad por omisión podría activar los derechos sociales y económicos de manera pronta, puesto que éstos deben establecer concretas obligaciones a cargo de los poderes públicos. Son directrices constitucionales y reglas de actuación administrativa inexcusables frente a su cumplimiento, por parte de los sujetos responsables. En el desarrollo práctico de la figura de la inconstitucionalidad por omisión se podría prever una responsabilidad patrimonial del Estado por daños causados por la inercia legislativa. Es cierto que correlativa a la obligación del Congreso a legislar existe el derecho subjetivo ciudadano a la legislación, que debe ser exigible por medio de este procedimiento de garantía constitucional, hoy en día ausente del ordenamiento jurídico colombiano.

Sólo queremos rematar este ensayo con las palabras del iuspublicista Hans-Peter Schneider:

Los derechos fundamentales son fin en sí mismos y expresión de la dignidad humana [...]. Son simultáneamente la conditio sine qua non del Estado constitucional democrático, puesto que no pueden dejar de ser pensados sin que peligre la forma de Estado o se transforma radicalmente.

\section{Bibliografía}

Aja, Eliseo. (1998) Las tensiones entre el Tribunal Constitucional y el Legislador en la Europa actual. Barcelona: Ariel.

Bazán, Víctor (coordinador). (1997) Inconstitucionalidad por omisión. Bogotá: Temis.

García de Enterría, Eduardo. (1991) La Constitución como norma y el Tribunal Constitucional ( $3^{a}$ edición). Madrid: Civitas.

Gomes Canotilho, José Joaquim. (1982) Constituicao dirigente e vinculacao do legislador. Coimbra: Coimbra Editora.

Gomes Canotilho, José Joaquim. (1993) Directo Constitucional ( $6^{\text {a }}$ edición). Coimbra: Livraria Almedina.

Gómez Puente, Marcos. (1977) La inactividad del legislador: una realidad susceptible de control. Madrid: McGraw-Hill.

Heller, Herman. (1987) Teoría del Estado. México: Fondo de Cultura Económica.

Hesse, Honrad. (1992) Escritos de Derecho Constitucional. Madrid: Centro de Estudios Constitucionales.

Ihering, Rudolf von. (1985) La lucha por el Derecho. Madrid: Civitas.

Kriele, Martín. (1980) Introducción a la teoría del Estado. Buenos Aires: Desalma, Buenos Aires.

Loewenstein, Kart. (1986) Teoría de la Constitución (2ª edición). Barcelona: Ariel. 
López Guerra, Luis. (1994) Introducción al Derecho Constitucional. Valencia: Tirant lo Blanch.

López Guzmán, Fabián. (2001) El derecho de empresa. La participación de los trabajadores. La cogestión. Bogotá: Gustavo Ibáñez.

Lucas Verdú, Pablo. (1972) Curso de Derecho Político (Vol. I). Madrid: Tecnos.
Miranda, Jorge. (1977) Inconstitucionalidade por omissao, en Estudos sobre a Constituicao (Vol. I). Livraria Petrony.

Schmitt, Carl. (1982) Teoría de la Constitución. Madrid: Alianza.

Silva García, Germán. (2002) El mundo real de los abogados y de la justicia. Bogotá: U. ExternadoILSA, Bogotá. 